\title{
Growth and yield of summer groundnut (Arachis hypogaea L.) as influenced by foliar application of water soluble fertilizer
}

\author{
S. Roy ${ }^{*}$, S.K. Gunri ${ }^{1}$, A. M. Puste ${ }^{1}$, A. Sengupta ${ }^{1}$ and D. Saha ${ }^{2}$ \\ ${ }^{1}$ Department of Agronomy, Bidhan Chandra Krishi Viswavidyalaya, Mohanpur, Nadia, (West Bengal-741252) \\ INDIA. \\ ${ }^{2}$ Department of Agronomy, College of Agriculture, Lembucherra, (Tripura-799210) INDIA \\ *Corresponding author. E-mail: sharmista3111989@ gmail.com
}

Received: June 6, 2015; Revised received: September 30, 2015; Accepted: February 20, 2016

\begin{abstract}
The field experiment was undertaken at the District Seed Farm, Kalyani at Bidhan Chandra Krishi Viswavidyalaya, Nadia, West Bengal during summer season of 2012 and 2013 to study the growth and yield of summer groundnut as influenced by application of water soluble foliar grade fertilizer. Application of liquid grade fertilizer at early growth stage up to $45 \mathrm{DAE}$ did not influence the plant height and dry matter production significantly, but towards maturity varied significantly $(P \leq 0.05)$. Crop growth rate was faster at early part of the crop age and gradually slows at later part towards maturity. Foliar application of water soluble fertilizer along with RDF $85 \%$ had the significant $(P \leq 0.05)$ influence to increase the number of pods per plant, but shelling percentage and hundred kernel weight did not vary significantly. Liquid grade fertilizer either starter dose or booster dose or in both had the positive response to increased the groundnut pod yield up to 4-6\% over RDF only. The crop was equally responsive in increasing the pod yield, when RDF was reduced by 15\% along with foliar application of liquid grade fertilizer. The foliar application of water soluble fertilizer was not the substitute to soil applied inorganic fertilizer. Instead, foliar supplementation of nutrients showed positive response to increase the pod yield, in addition to the fertilizers added to soil. Gross return decreased with reduction in amount of RDF applied for the crop, but gross return increased, when water soluble foliar grade inorganic fertilizer was supplemented with RDF. The maximum gross return of ₹150399 was obtained. The results obtained from correlation analysis carried out to examine the linear relationship between pod yields with different plant characters. Data obtained in case of dry matter of the plant was 0.995 and 0.997 in the respective years at $1 \%$ level of significance. Thus, it was concluded that dry matter content of plant is solely responsible over the yield increase in groundnut and foliar application of inorganic fertilizers in addition to that in soil has helped in better adsorption of nutrients in adequate amount by the crop.
\end{abstract}

Keywords: Correlation analysis, Foliar fertilization, Groundnut, Growth and yield attributes, Regression analysis and Yield

\section{INTRODUCTION}

Groundnut (Arachis hypogaea L.) is one of the most important annual legumes. It is important source of edible oil $(50 \%)$ and third most important source of vegetable protein (25 - 30\%) grown on 26.4 million ha worldwide with a total production of 37.1 million metric tonne and an average productivity of 1.4 metric t/ha (Kalamkar et al., 2006).

The major groundnut producing countries in the world are India, China, Nigeria, Senegal, Sudan, Burma and the United States of America. However, in West Bengal, is low which could be attributed to cultivation of oilseed crops is mostly done on marginal lands, which are lacking in irrigation and low levels of inputs used there. Moreover, severe mineral nutrient deficiencies due to imbalanced fertilizers are one of the major factors responsible for low yield. (Kabir et al., 2013).

Besides, groundnut is an exhaustive crop compared to other legumes because a very little portion of the plant residue is left in the soil after harvest (Varade and
Urkude, 1982). Soil applied Fertilizers are subjected to different losses like, leaching losses of nitrogenous fertilizers, fixation and unavailability of phosphatic fertilizers. Therefore, the use efficiency of applied fertilizers is low and soil application of nutrients may not produce desirable yields. Under these circumstances foliar application seems to be promising for ensuring use efficiency of applied nutrients.

The purpose of foliar feeding is not to replace soil fertilization, but rather to supplement plant nutrient needs during short and/or critical growth stages. Foliar feeding of a nutrient might have actually promoted root absorption of the same nutrient or other nutrients through improving root growth and increasing nutrients uptake (El-Fouly and El-Sayed, 1997). Even vermi-compost wash, if sprayed at optimum concentrations could give higher yield and yield contributing characters (Hiradeve et al., 2011). Not all fertilizers are suitable for use in foliar applications. Fertilizers should meet the standard of high solubility and high purity. During the last decades, foliar feeding of nutri- 
ents has become an established procedure in crop production to increase yield and improve the quality of crop products (Roemheld and El-Fouly, 1999). In view of the above fact it was considered worthwhile to undertake the investigation in order to evaluate the vertical expansion (productivity enhancement) of groundnut through supplementation of water-soluble foliar grade fertilizers with soil application at 5\% level of significance to sustain the groundnut yield.

\section{MATERIALS AND METHODS}

Study Area: The experiment was undertaken at District Seed Farm (DSF), Kalyani under Bidhan Chandra Krishi Viswavidyalaya, Nadia, West Bengal during summer season of 2012 and 2013. The farm is situated at $23.5 \mathrm{~N}$ latitude and $89.0 \mathrm{E}$ longitude with an average altitude of $9.75 \mathrm{~m}$ above mean sea level. The initial field soil characteristics were, viz. $\mathrm{pH}$ (7.1) and organic carbon $(0.49 \%)$ were analyzed following the analytical procedure of Jackson (1973). The design of the experiment was in randomized block design (RBD) with twelve (12) treatments and replicated three times. Each plot of the experimental field was of area $15 \mathrm{~m}^{2}(3 \mathrm{~m} \times 5 \mathrm{~m})$, with a spacing of $30 \mathrm{~cm}$ row to row and $10 \mathrm{~cm}$ plant to plant during both the years. The details of the treatments were: $\mathrm{T}_{1}=$ Absolute control (No FYM, no RDNPK and no foliar application of water soluble grade fertilizer), $\mathrm{T}_{2}=$ FYM $7.5 \mathrm{t}$ / ha $+100 \%$ Recommended dose of fertilizer (RDNPK) (20:60:40), $\mathrm{T}_{3}=$ Foliar application of starter dose of water soluble grade fertilizer $(11: 36: 24$ + trace elements (borax 2\%)@2\% at 30 DAE+ Foliar application of booster dose of water soluble grade fertilizer (8:16:39+ trace element (borax 2\%) @2\% at $45 \mathrm{DAE}$ and $60 \mathrm{DAE}, \mathrm{T}_{4}=$ Foliar application of starter dose of water soluble grade fertilizer [(17:44:0 +SOP (17:50)] @ $5 \mathrm{~g}$ of each /lit of water $30 \mathrm{DAE}+$ Foliar application of booster dose of water soluble grade fertilizer [(8:22:0+SOP (17:50)] $5 \mathrm{~g}$ each at $45 \mathrm{DAE}$ and 60 DAE (2.5g each of per liter), $\mathrm{T}_{5}=$ FYM $7.5 \mathrm{t} / \mathrm{ha}+100$ $\%$ Recommended dose of fertilizer (RDNPK) $(20: 60: 40)+\mathrm{T}_{3}, \mathrm{~T}_{6}=$ FYM $7.5 \mathrm{t} / \mathrm{ha}+100 \%$ Recommended dose of fertilizer (RDNPK) $(20: 60: 40)+\mathrm{T}_{4}$, $\mathrm{T}_{7}=$ FYM $7.5 \mathrm{t} / \mathrm{ha}+85 \%$ Recommended dose of fertilizer (RDNPK) (20:60:40), $\mathrm{T}_{8}=\mathrm{FYM} 7.5 \mathrm{t} / \mathrm{ha}+$ $85 \%$ Recommended dose of fertilizer (RDNPK) $(20: 60: 40)+\mathrm{T}_{3}, \mathrm{~T}_{9}=$ FYM $7.5 \mathrm{t} / \mathrm{ha}+85 \%$ Recommended dose of fertilizer (RDNPK) (20:60:40) $+\mathrm{T}_{4}$, $\mathrm{T}_{10}=\mathrm{FYM} 7.5 \mathrm{t} / \mathrm{ha}+60 \%$ Recommended dose of fertilizer $\left(\right.$ RDNPK) $(20: 60: 40), \mathrm{T}_{11}=$ FYM $7.5 \mathrm{t} / \mathrm{ha}+$ $60 \%$ Recommended dose of fertilizer (RDNPK) $(20: 60: 40)+\mathrm{T}_{3}, \mathrm{~T}_{12}=$ FYM $7.5 \mathrm{t} / \mathrm{ha}+60 \%$ Recommended dose of fertilizer (RDNPK) (20:60:40) $+\mathrm{T}_{4}$. The recommended doses of inorganic fertilizers were 20:60:40 kg ha ${ }^{-1}$ of $\mathrm{N}, \mathrm{P}_{2} \mathrm{O}_{5}$ and $\mathrm{K}_{2} \mathrm{O}$ and Farm Yard Manure@ $0.5 \mathrm{t} / \mathrm{ha}$. For the water soluble liquid grade fertilizer application (11:36:24 and 8:16:39) the preparation was made from inorganic sources as mentioned.
For nitrogen the source was $\left(\mathrm{NH}_{4}\right)_{2} \mathrm{SO}_{4}$ (Ammonium sulphate) and for $\mathrm{P}$ and $\mathrm{K}$ the source was $\mathrm{KH}_{2} \mathrm{PO}_{4}$ (Potassium dihydrogen phosphate) and $\mathrm{KCl}$; and for the water-soluble foliar grade fertilizer 17:44:0 + SOP $(17: 50)$ and 8:22:0 was from the technical grade prepared by IFFCO. Trace element boron (micronutrient) in the form of borax (11.4 - 12\% boron content) @2\% was applied as per the treatment schedule of the experiment. Gypsum @ $400 \mathrm{~kg} \mathrm{ha}^{-1}$ was applied uniformly in all the treatments during both the years. The groundnut variety TG 51 (BARC released) was sown on $19^{\text {th }}$ and $22^{\text {nd }}$ February during 2012 and 2013 respectively.

Observations recorded: The biometrical observations taken during the crop growth were like plant height $(\mathrm{cm})$, dry matter accumulation $\left(\mathrm{g} \mathrm{m}^{-2}\right)$, crop growth rates $\left(\mathrm{g} \mathrm{m}^{-2} \mathrm{day}^{-1}\right)$, number of nodules per plant and nodule dry weight $\left(\mathrm{mg} \mathrm{plant}^{-1}\right)$ at 15 days interval from 30 days after crop emergence. The yield attributes observed were, number of pods per plant, shelling percentage, 100 kernel weight (g). And the yield parameters recorded were pod yield $\left(\mathrm{kg} \mathrm{ha}^{-1}\right)$, haulm yield $(\mathrm{kg}$ $\mathrm{ha}^{-1}$ ) and harvesting index (\%).

Statistical analysis: Statistical analysis of data relating to growth, yield parameters and yield data was carried out by using MSTAT following analysis of variance method (Gomez and Gomez, 1984). For comparison of ' $F$ ' values and computation of critical difference (CD) at 5\% level of significance, Fisher and Yates' tables were consulted. Correlation analysis was done to represent the degree of association between pod yields of groundnut with different plant attributes. Multiple stepwise linear regression analysis between pod yields with different plant characters was carried out in order to identify the most contributing factor.

\section{RESULTS AND DISCUSSION}

Growth attributing characteristics: During the present study plant height increased with increase in age of the crop towards maturity. Application of liquid grade fertilizer at early stage up to $45 \mathrm{DAE}$ did not influence the plant height significantly. Significant $(P$ $\leq 0.05$ ) variation of plant height was observed due to application of water soluble liquid grade fertilizer at 60 and 75 DAE (Table 1). The maximum plant height was recorded with the treatment $\mathrm{T}_{6}$ received $100 \% \mathrm{RDF}+$ $7.5 \mathrm{t} \mathrm{ha}^{-1}$ of FYM $+\mathrm{T}_{4}$. At harvest plant height did not vary significantly.

From the table 1, it was revealed that at early growth stage dry matter production gradually increased with increasing the age of the crop but did not vary significantly due to treatments effect. But at later part of the crop growth at 60 and 75 DAE dry matter production varied significantly $(\mathrm{P} \leq 0.05)$ and highest dry matter production was found in the treatment $T_{2}$ at 60 and 75 DAE and at harvest it was $\mathrm{T}_{6}$. So, foliar application of water soluble fertilizer showed positive response in increasing the dry matter accumulation at later stage. This might be due to the fact that foliar applications 
Table 1. Crop growth of groundnut as influenced by water soluble foliar grade fertilizer (Pooled over years 2012 and 2013 ).

\begin{tabular}{|c|c|c|c|c|c|c|c|c|c|c|c|c|}
\hline \multirow[b]{2}{*}{ Treatments } & \multicolumn{4}{|c|}{ Plant height (cm) } & \multicolumn{4}{|c|}{ Dry Matter Production $\left(\mathrm{g} \mathrm{m}^{-2}\right)$} & \multicolumn{4}{|c|}{ Crop Growth Rate $\left(\mathrm{g} \mathrm{m}^{-2} \mathrm{day}^{-1}\right)$} \\
\hline & $\begin{array}{l}45 \\
\text { DAE }\end{array}$ & $\begin{array}{l}60 \\
\text { DAE }\end{array}$ & $\begin{array}{l}75 \\
\text { DAE } \\
\end{array}$ & $\begin{array}{l}\text { At har- } \\
\text { vest }\end{array}$ & 45 DAE & 60 DAE & $\begin{array}{l}75 \\
\text { DAE }\end{array}$ & $\begin{array}{l}\text { At } \\
\text { harvest }\end{array}$ & $\begin{array}{l}30-45 \\
\text { DAE }\end{array}$ & $\begin{array}{l}46-60 \\
\text { DAE }\end{array}$ & $\begin{array}{l}\text { 61-75 } \\
\text { DAE }\end{array}$ & $\begin{array}{l}76 \text { to } \\
\text { harvest }\end{array}$ \\
\hline$\overline{\mathrm{T}_{1}}$ & 23.86 & 35.66 & 45.84 & 48.43 & 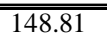 & 165.84 & 17178.01 & 190.40 & 4.06 & 1.14 & 0.81 & 0.81 \\
\hline $\mathrm{T}_{2}$ & 27.32 & 42.47 & 51.93 & 54.88 & 193.03 & 305.05 & 426.67 & 443.70 & 6.48 & 7.47 & 8.11 & 1.50 \\
\hline $\mathrm{T}_{3}$ & 25.86 & 41.36 & 50.60 & 54.30 & 175.07 & 271.60 & 368.67 & 389.85 & 6.50 & 6.44 & 6.47 & 1.52 \\
\hline $\mathrm{T}_{4}$ & 26.70 & 42.72 & 51.18 & 53.80 & 181.04 & 281.13 & 371.49 & 394.60 & 6.37 & 6.67 & 6.03 & 2.14 \\
\hline $\mathrm{T}_{5}$ & 28.70 & 46.68 & 53.19 & 55.44 & 203.46 & 279.56 & 404.64 & 447.70 & 7.10 & 5.08 & 8.34 & 2.89 \\
\hline $\mathrm{T}_{6}$ & 28.92 & 46.75 & 54.65 & 54.69 & 200.64 & 282.23 & 409.53 & 450.20 & 6.92 & 5.44 & 8.49 & 2.17 \\
\hline $\mathrm{T}_{7}$ & 26.82 & 42.77 & 51.23 & 53.86 & 187.92 & 290.34 & 386.88 & 410.45 & 6.76 & 6.83 & 6.44 & 2.00 \\
\hline $\mathrm{T}_{8}$ & 27.13 & 44.81 & 52.42 & 54.53 & 206.92 & 303.95 & 402.50 & 436.55 & 8.06 & 6.47 & 6.57 & 1.99 \\
\hline $\mathrm{T}_{9}$ & 27.68 & 44.81 & 52.53 & 55.03 & 212.89 & 301.95 & 417.83 & 447.25 & 9.03 & 5.94 & 7.73 & 1.60 \\
\hline $\mathrm{T}_{10}$ & 26.06 & 41.48 & 49.84 & 52.09 & 177.25 & 284.56 & 355.76 & 372.55 & 6.52 & 7.16 & 4.75 & 1.15 \\
\hline $\mathrm{T}_{11}$ & 26.37 & 42.22 & 51.64 & 53.95 & 191.12 & 287.92 & 367.89 & 394.95 & 7.06 & 6.45 & 5.33 & 1.50 \\
\hline $\mathrm{T}_{12}$ & 26.57 & 42.15 & 51.62 & 53.61 & 180.32 & 288.77 & 359.26 & 397.15 & 6.42 & 7.23 & 4.70 & 2.48 \\
\hline $\operatorname{SEm}( \pm)$ & 0.982 & 1.401 & 0.956 & 1.896 & 16.302 & 11.346 & 32.345 & 28.611 & 1.154 & 1.267 & 2.036 & 7.926 \\
\hline $\mathrm{CD}(\mathrm{p}=0.05)$ & NS & 3.963 & 2.704 & NS & NS & 32.087 & 91.471 & 80.912 & NS & NS & NS & NS \\
\hline
\end{tabular}

Table 2. Nodulation and yield attributes of groundnut as influenced by water soluble foliar grade fertilizer (Pooled over years 2012 and 2013 ).

\begin{tabular}{|c|c|c|c|c|c|c|c|c|c|}
\hline \multirow[b]{2}{*}{ Treatments } & \multicolumn{3}{|c|}{ Number of nodules plant $^{-1}$} & \multicolumn{3}{|c|}{ Nodule dry weight $\left(\mathrm{mg} \mathrm{plant}^{-1}\right)$} & \multicolumn{3}{|c|}{ Yield attributes } \\
\hline & 30 DAE & 45 DAE & 60 DAE & 30 DAE & 45 DAE & 60 DAE & $\begin{array}{l}\text { Number of } \\
\text { pods } \\
\text { plant }^{-1}\end{array}$ & $\begin{array}{l}\text { Shelling } \\
(\% 0)\end{array}$ & $\begin{array}{l}100 \\
\text { Kernel Weight } \\
\text { (g) }\end{array}$ \\
\hline$\overline{\mathrm{T}_{1}}$ & 10.03 & 14.65 & 18.71 & 0.19 & 0.28 & 0.32 & 11.14 & 66.81 & 43.88 \\
\hline $\mathrm{T}_{2}$ & 12.64 & 18.50 & 25.78 & 0.24 & 0.38 & 0.36 & 19.31 & 70.17 & 45.49 \\
\hline $\mathrm{T}_{3}$ & 9.41 & 17.91 & 22.91 & 0.13 & 0.25 & 0.42 & 16.33 & 69.87 & 45.68 \\
\hline $\mathrm{T}_{4}$ & 11.53 & 17.72 & 20.24 & 0.18 & 0.38 & 0.44 & 16.27 & 69.94 & 46.43 \\
\hline $\mathrm{T}_{5}$ & 10.94 & 17.82 & 22.13 & 0.63 & 0.29 & 0.30 & 19.92 & 71.49 & 48.25 \\
\hline $\mathrm{T}_{6}$ & 10.25 & 20.00 & 23.34 & 0.21 & 0.37 & 0.39 & 20.89 & 70.65 & 47.70 \\
\hline $\mathrm{T}_{7}$ & 9.90 & 16.62 & 19.96 & 0.29 & 0.93 & 0.35 & 16.78 & 68.91 & 48.04 \\
\hline $\mathrm{T}_{8}$ & 13.41 & 17.93 & 26.99 & 0.36 & 0.38 & 0.25 & 20.47 & 70.69 & 48.17 \\
\hline $\mathrm{T}_{9}$ & 11.27 & 18.16 & 26.37 & 0.16 & 0.94 & 1.81 & 19.29 & 70.28 & 48.08 \\
\hline $\mathrm{T}_{10}$ & 11.77 & 16.35 & 21.41 & 0.23 & 0.27 & 0.83 & 15.91 & 68.66 & 46.27 \\
\hline $\mathrm{T}_{11}$ & 10.01 & 17.95 & 23.99 & 1.12 & 0.36 & 3.32 & 16.73 & 69.00 & 47.41 \\
\hline $\mathrm{T}_{12}$ & 13.62 & 16.12 & 27.16 & 0.31 & 0.35 & 3.47 & 17.48 & 69.30 & 47.79 \\
\hline $\operatorname{SEm}( \pm)$ & 2.048 & 2.574 & 3.140 & 0.149 & 0.200 & 0.396 & 0.976 & 1.822 & 1.410 \\
\hline $\mathrm{CD}(\mathrm{p}=0.05)$ & NS & NS & NS & NS & NS & 1.122 & 2.760 & NS & NS \\
\hline
\end{tabular}

Table 3. Yield and economics of groundnut as influenced by water soluble foliar grade fertilizer (Pooled over years 2012 and 2013).

\begin{tabular}{|c|c|c|c|c|c|c|}
\hline Treatments & Pod yield $\left(\mathrm{kg} \mathrm{ha}^{-1}\right)$ & Haulm yield $\left(\mathrm{kg} \mathrm{ha}^{-1}\right)$ & Harvest Index (\%) & Gross return (₹/ha) & Total cost (₹/ha) & Net return : Cost \\
\hline$\overline{\mathrm{T}_{1}}$ & 1252 & 1904 & 39.54 & 50563 & 36263 & 0.39 \\
\hline $\mathrm{T}_{2}$ & 3588 & 4437 & 44.76 & 144636 & 46589 & 1.73 \\
\hline $\mathrm{T}_{3}$ & 3105 & 3899 & 44.54 & 125148 & 37898 & 2.29 \\
\hline $\mathrm{T}_{4}$ & 3174 & 3943 & 44.66 & 127926 & 37377 & 2.45 \\
\hline $\mathrm{T}_{5}$ & 3664 & 4477 & 45.53 & 147660 & 48224 & 2.02 \\
\hline $\mathrm{T}_{6}$ & 3732 & 4502 & 45.50 & 150399 & 47703 & 2.11 \\
\hline $\mathrm{T}_{7}$ & 3417 & 4105 & 45.44 & 137706 & 40888 & 2.39 \\
\hline $\mathrm{T}_{8}$ & 3662 & 4366 & 45.50 & 147552 & 42523 & 2.56 \\
\hline $\mathrm{T}_{9}$ & 3730 & 4473 & 45.67 & 150332 & 42002 & 2.69 \\
\hline $\mathrm{T}_{10}$ & 3026 & 3759 & 44.71 & 121960 & 39733 & 2.27 \\
\hline $\mathrm{T}_{11}$ & 3235 & 3950 & 44.93 & 130375 & 41368 & 2.26 \\
\hline $\mathrm{T}_{12}$ & 3281 & 3972 & 44.92 & 132240 & 40847 & 2.44 \\
\hline $\operatorname{SEm}( \pm)$ & 128.61 & 183.21 & 1.906 & 5132.1 & 36263 & 0.128 \\
\hline $\mathrm{CD}(\mathrm{P}=0.05)$ & 363.72 & 536.33 & NS & 14513.5 & 46589 & 0.362 \\
\hline
\end{tabular}

Table 4. Correlation Matrix of Pod Yield with different Plant Character of Groundnut during 2012.

\begin{tabular}{|c|c|c|c|c|c|c|c|c|}
\hline Plant Character & $\begin{array}{l}\text { Pod } \\
\text { Yield }\end{array}$ & $\begin{array}{l}\text { Dry } \\
\text { Matter }\end{array}$ & $\begin{array}{l}\text { Nodule } \\
\text { /plant }\end{array}$ & $\begin{array}{l}\text { No. of } \\
\text { pod/plant }\end{array}$ & $\begin{array}{l}\text { Pod dry } \\
\text { weight/plant }\end{array}$ & $\begin{array}{l}\text { Shelling } \\
(\%)\end{array}$ & $\begin{array}{l}\text { Hundred Ker- } \\
\text { nel Weight }\end{array}$ & $\begin{array}{l}\text { Harvest } \\
\text { Index }\end{array}$ \\
\hline Pod Yield & 1.000 & $0.995 * *$ & $0.504^{*}$ & $0.835 * *$ & $0.768 * *$ & $0.797 * *$ & $0.854 * *$ & $0.972 * *$ \\
\hline Dry Matter & & 1.000 & $0.535^{*}$ & $0.823 * *$ & $0.737 * *$ & $0.829 * *$ & $0.837 * *$ & $0.956 * *$ \\
\hline Nodule/plant & & & 1.000 & $0.586^{*}$ & 0.493 & $0.589^{*}$ & 0.447 & 0.312 \\
\hline No. of pod/plant & & & & 1.000 & $0.820 * *$ & $0.751 * *$ & $0.839 * *$ & $0.758 * *$ \\
\hline Pod dry weight/plant & & & & & 1.000 & $0.660 * *$ & $0.900 * *$ & $0.717 * *$ \\
\hline Shelling (\%) & & & & & & 1.000 & $0.747 * *$ & $0.709 * *$ \\
\hline Hundred Kernel Weight & & & & & & & 1.000 & $0.815^{* *}$ \\
\hline Harvest Index & & & & & & & & 1.000 \\
\hline
\end{tabular}

Note: ** means significant at $1 \%$ level; * means significant at $5 \%$ level. 
Table 4 a. Correlation Matrix of pod yield with different plant characters of Groundnut during 2013.

\begin{tabular}{|c|c|c|c|c|c|c|c|c|}
\hline Plant Character & $\begin{array}{l}\text { Pod } \\
\text { Yield }\end{array}$ & $\begin{array}{l}\text { Dry } \\
\text { Matter }\end{array}$ & $\begin{array}{l}\text { Nodule } \\
\text { /plant }\end{array}$ & $\begin{array}{l}\text { No. of pod/ } \\
\text { plant }\end{array}$ & $\begin{array}{l}\text { Pod dry } \\
\text { weight/plant }\end{array}$ & $\begin{array}{l}\text { Shelling } \\
(\%)\end{array}$ & $\begin{array}{l}\text { Hundred Kernel } \\
\text { Weight }\end{array}$ & $\begin{array}{l}\text { Harvest } \\
\text { Index }\end{array}$ \\
\hline Pod Yield & 1.000 & $0.997 * *$ & $0.505^{*}$ & $0.941 * *$ & $0.814 * *$ & $0.872 * *$ & $0.684 * *$ & $0.954 * *$ \\
\hline Dry Matter & & 1.000 & 0.490 & $0.936 * *$ & $0.803 * *$ & $0.884 * *$ & $0.653 *$ & $0.936 * *$ \\
\hline Nodule/plant & & & 1.000 & 0.486 & $0.690 * *$ & 0.370 & $0.530 *$ & $0.511 *$ \\
\hline No. of pod/plant & & & & 1.000 & $0.898 * *$ & $0.883 * *$ & $0.588 *$ & $0.855^{* *}$ \\
\hline Pod dry weight/plant & & & & & 1.000 & $0.772 * *$ & $0.666 * *$ & $0.717 * *$ \\
\hline Shelling $(\%)$ & & & & & & 1.000 & $0.546^{*}$ & $0.777 * *$ \\
\hline Hundred Kernel Weight & & & & & & & 1.000 & $0.727 * *$ \\
\hline Harvest Index & & & & & & & & 1.000 \\
\hline
\end{tabular}

Note: ** means significant at $1 \%$ level ; * means significant at $5 \%$ level.

Table 4 b. Correlation Matrix of Pod Yield with different plant characters of Groundnut (pooled over two years).

\begin{tabular}{|c|c|c|c|c|c|c|c|c|}
\hline Plant Character & $\begin{array}{l}\text { Pod } \\
\text { Yield }\end{array}$ & $\begin{array}{l}\text { Dry } \\
\text { Matter }\end{array}$ & $\begin{array}{l}\text { Nodule } \\
\text { /plant }\end{array}$ & $\begin{array}{l}\text { No. of } \\
\text { pod/plant }\end{array}$ & $\begin{array}{l}\text { Pod dry } \\
\text { weight/plant }\end{array}$ & $\begin{array}{l}\text { Shelling } \\
(\%)\end{array}$ & $\begin{array}{l}\text { Hundred Kernel } \\
\text { Weight }\end{array}$ & $\begin{array}{l}\text { Harvest } \\
\text { Index }\end{array}$ \\
\hline $\begin{array}{l}\text { Pod Yield } \\
\text { Dry Matter } \\
\text { Nodule/plant } \\
\text { No. of pod/plant } \\
\text { Pod dry weight/plant } \\
\text { Shelling (\%) } \\
\text { Hundred Kernel Weight } \\
\text { Harvest Index }\end{array}$ & 1.000 & $\begin{array}{l}0.997^{* * *} \\
1.000\end{array}$ & $\begin{array}{l}0.598 * \\
0.588 * \\
1.000\end{array}$ & $\begin{array}{l}0.929 * * \\
0.931 * * \\
0.663 * * \\
1.000\end{array}$ & $\begin{array}{l}0.800 * * \\
0.784 * * \\
0.755 * * \\
0.883 * * \\
1.000\end{array}$ & $\begin{array}{l}0.867 * * \\
0.887 * * \\
0.505 * \\
0.915 * * \\
0.772 * * \\
1.000\end{array}$ & $\begin{array}{l}0.795 * * \\
0.759 * * \\
0.462 \\
0.740^{* *} \\
0.818^{* *} \\
0.642 * \\
1.000\end{array}$ & $\begin{array}{l}0.975^{* *} \\
0.965^{* *} \\
0.524 * \\
0.843^{* *} \\
0.733^{* *} \\
0.792^{* *} \\
0.826 * * \\
1.000\end{array}$ \\
\hline
\end{tabular}

Note: ** means significant at $1 \%$ level; * means significant at $5 \%$ level.

Table 4 c. Multiple step-wise linear regressions between pod yield with different plant characters of Groundnut.

\begin{tabular}{cll}
\hline \hline Period & Regression equation & Parameters \\
\hline \hline \multirow{2}{*}{ During 2012 } & $\mathrm{Y}=-543.626+9.524 \mathrm{X} 1$ & $\mathrm{X} 1:$ Dry matter X7 : Harvest Index \\
& $\mathrm{Y}=-3473.695+7.335 \mathrm{X} 1+84.436 \mathrm{X} 7$ & $\mathrm{X} 4:$ Pod dry weight/plant \\
& $\mathrm{Y}=-3294.332+6.943 \mathrm{X} 1+80.967 \mathrm{X} 7+5.114 \mathrm{X} 4$ & $\mathrm{X} 1:$ Dry matter \\
During 2013 & $\mathrm{Y}=-534.305+9.464 \mathrm{X} 1$ & $\mathrm{X} 7:$ Harvest Index \\
& $\mathrm{Y}=-3378.512+7.981 \mathrm{X} 1+77.402 \mathrm{X} 7$ & $\mathrm{X} 4:$ Pod dry weight/plant \\
& $\mathrm{Y}=-3575.917+7.423 \mathrm{X} 1+84.537 \mathrm{X} 7+3.232 \mathrm{X} 4$ & $\mathrm{X} 1:$ Dry matter \\
Pooled over two years & $\mathrm{Y}=-545.181+9.508 \mathrm{X} 1$ & $\mathrm{X} 6:$ Hundred Kernel Weight \\
& $\mathrm{Y}=-2309.691+8.871 \mathrm{X} 1+43.001 \mathrm{X} 6$ & $\mathrm{X} 5:$ Shelling $(\%)$ \\
\hline \hline
\end{tabular}

could stimulate more vigorous re-growth, thereby increasing the yield potential. Similar observation was also reported by Patil et al. (1999) that dry matter accumulation was significantly $(\mathrm{P} \leq 0.05)$ increased due to foliar spray of 5-30\% methanol spray. And Sarkar et al. (1999) recorded greatest plant height, maximum dry matter production as well as growth rate when leaves of groundnut were sprayed with $0.25 \% \mathrm{KNO}_{3}+$ $0.203 \% \mathrm{Ca}\left(\mathrm{NO}_{3}\right)_{2}$. Foliar application of water soluble fertilizer along with or without organic fertilizer application to groundnut did not show the significant variation of crop growth rate at all the growth stages of the crop. From the table 1, it was found that the crop growth rate was faster at early part of the crop age and gradually slows at later part towards maturity. The reason behind could be greater and faster absorption of water soluble fertilizer at early stage than later stage of the crop. These observations were in support to that reported by Amandeep et al. (2004) which stated that, foliar application of mepiquat chloride during flowering and vegetative stages of groundnut, improved the number of branches and leaf area indices, while spraying during the podding stage did not significantly affect the parameters. Similarly, Veerabhadrappa et al. (2005) observed that after the soil and foliar application of three graded levels of fertilizers at three crop stages (30, 45 and 60 days of sowing), the concentrations of nutrients in plant parts were recorded higher at 30 DAS than at later stages.

Number of nodules and nodule dry weight per plant increased with increasing the age of the crop and was found maximum up to at 60 DAE. Application of organic and inorganic fertilizers along with water soluble fertilizer had the positive response to increase the nodule numbers. At all the growth stages nodule numbers increased with fertilizer application both liquid and solid grade but they were not varied significantly $(\mathrm{P} \leq$ 0.05) among each other. This might be due to the application of nitrogen fertilizer tended to depress the formation of root nodules. Namo and Dowyaro, (2009) opined alike stating in their report that the number of root nodules and total dry matter increased with crop age across variety rate and time of $\mathrm{N}$ - application in rainfed groundnut. Vanilarasu and Balakrishnamurthy, (2014) reported that the increase in available nitrogen may also due to application of FYM which converts organically bound $\mathrm{N}$ to inorganic form during mineralization resulting in higher available nitrogen of soil and higher number of nodule formation.

Yield attributing characteristics: All the yield attributing characters increased significantly $(\mathrm{P} \leq 0.05)$ due to application of foliar grade water soluble fertilizer. 
Number of pods per plant increased with increasing level of fertilizer. The highest number of pods per plant was recorded with the treatment $\mathrm{T}_{6}(20.89)$. From the table 3 , it was found that the foliar application of water soluble fertilizer along with RDF $85 \%$ had the significant influence to increase the number of pods per plant. Similar observation was also reported by Patra et al. (1995). He conducted a trial on groundnut varieties to investigate foliar application of $0.5 \%$ $\mathrm{KNO}_{3}, 0.5 \% \mathrm{Ca}\left(\mathrm{NO}_{3}\right)_{2}$ or $2 \%$ urea (at $50 \%$ flowering and again 20 days later). It resulted in an increase in growth rate, pods/plant as well as 100 kernel weight. Shelling percentage and hundred kernel weight of groundnut did not differ significantly due to application of foliar grade water soluble fertilizer along with or without $100 \%, 85 \%$ or $60 \%$ of RDF. The data presented in table 3 revealed that pod yield increased with increasing level of fertilizer application to groundnut. Foliar grade water soluble fertilizers application to groundnut had the positive response to increase the pod yield either alone or in combined with recommended fertilizer dose. The data presented in table 3 revealed that pod yield increased with the application of liquid grade fertilizer along with soil application of inorganic fertilizer to groundnut. From the table 3 , it was observed that the liquid grade fertilizer either starter dose or booster dose or in both had positive response to increase the groundnut pod yield up to 4 $6 \%$ over RDF only. The crop was equally responsive to increase the pod yield, when RDF was reduced by $15 \%$ ( $85 \%$ of RDF) along with foliar application of liquid grade fertilizer.

This might be due to groundnut being a legume crop at initial stage, soil application of nitrogenous fertilizer requirement is less (only 20-40\% nitrogen was taken from soil) and in addition at later stage due to supplementation of water soluble foliar grade fertilizer could improve the nutrient utilization and lower environmental pollution through reducing the amounts of fertilizers added to soil as a result the yield was high. But further reduction in the level of inorganic fertilizer (upto $60 \%$ of $\mathrm{RDF}$ ) did not prove beneficial to groundnut. The foliar application of water soluble fertilizer was not substitute like soil application of inorganic (solid grade) fertilizer but supplementation had the positive response to increase the pod yield. The application of $80 \mathrm{~kg} \mathrm{ha}^{-1}$ nitrogen along with zinc foliar application enhanced the seed yield to $3742 \mathrm{~kg}$ ha $^{-1}$ (Pendashtek et al., 2011).

This might be due to foliar application of nutrients, which normally reduces the loss through absorption, leaching and other processes associated with soil application and its application prompt correction of nutrient deficiencies. Similar finding was also reported Balerao et al. (1994) where he stated that mean dry pod yield was increased by $5.6-20 \%$ by foliar applications including individual or combined trace elements, urea, phosphorus and plant growth regulators (tricontanol).
Harvesting index did not vary significantly $(\mathrm{P} \leq 0.05)$ due to application of water soluble foliar grade fertilizer with or without applied fertilizer in soil.

From the table 3, it was found that the gross return decreased with decrease of RDF but gross return increased, when water soluble foliar grade inorganic fertilizer was supplemented with RDF irrespective of their doses. The highest gross return (₹150399) was recorded in $\mathrm{T}_{6}$. The highest net return: cost was recorded in the treatment $\mathrm{T}_{9}(2.70)$.

Correlation and regression analysis: Tables 4 , 4a and $4 \mathrm{~b}$ represents the degree of association between pod yield of groundnut with different plant attributes (dry matter content, nodule per plant, number of pods per plant, pod dry weight per plant, shelling percentage, hundred kernel weight and harvest index) during two individual year (2012 and 2013) as well as pooled over the two. The tables clearly envisage the fact that pod yield of groundnut has a strong positive relationship with different plant attributes taken under consideration. The range of association varies from $50.0 \%$ (with nodule per plant) to almost cent percent with dry matter content indicating a heavy level of influence over the pod yield. The results obtained from correlation analysis were $0.995,0.997$ for dry matter of year 2012 and 2013 respectively with pod yield of the crop. Pooled data over two years (0.997) has also registered similar phenomenon with different plant characteristics. This relationship was highly significant at $1 \%$ probability level.

Multiple stepwise linear regressions between pod yields with different plant characters have been performed in order to identify the most contributing factor. Among all the factors, dry matter content has been contributed the bulk regarding pod yield followed by harvesting index of the crop and pod dry weight per plant in both the year. However, the parity of the factor breaks, when two years are taken together as the pooled data has registered two different contributing factors such as hundred kernel weight and shelling percentage. Overall, the study concludes that dry matter content of plant is solely responsible over the yield gaining in groundnut over the years (Table 4c).

\section{Conclusion}

From the above experiment, it could be concluded that the application of inorganic fertilizers can be reduced upto $15 \%$ when foliar grade water soluble fertilizer either 11:36:24 and 8:16:39 @ 2\% or 17:44:0 + Sulphate of Potash (17:50) and 8:22:0 + SOP (17:50) @ $5 \mathrm{~g}$ of each/lit of water was supplemented at $30 \mathrm{DAE}$ as a starter dose and at $45 \mathrm{DAE}$ and $60 \mathrm{DAE}$ as booster dose respectively to achieve optimum yield as well as highest benefit: cost ratio. Thus, it was concluded that the practice of foliar nutrition when used as a supplement and not a substitute for standard soil fertilization, was beneficial for summer groundnut. 


\section{REFERENCES}

Amandeep, Parmar,U and Singh,P. (2004). Efficacy of mepiquat chloride as foliar application at three stages of groundnut (Arachis hypogaea L.) cv M-335. Environment and Ecology. 22(4): 783-786.

Balerao, P.D.; Jadhao, P.N. and Fulzele, G.R. (1994). Response of groundnut to foliar application of nutrients and growth stimulant. Journal of Maharashtra Agricultural-Universities. 19(1): 94-96.

El-Fouly, M.M. and El-Sayed, A.A. (1997). Foliar Fertilization: An environmentally friendly application of fertilizers. Dahlia Greidinger International symposium on "Fertilization and Environment" 24-27 March, Haifa, Israel, Ed. John, J. 346-357.

Gomez, K. A. and Gomez, A. A. 1984. Statistical procedures for Agricultural Research (2nd Ed.). An International Rice Research Institute Book. A Willey Inter-science Publication (John Willey and Sons), New York: 258259.

Hiradeve, P.N; Deotale, R.D; Deogirkar, M.S. and Gaikwad, S.B. (2011). Effectivity of foliar sprays of vermicompost wash on chemical, biochemical, yield and yield contributing parameters of groundnut (Arachis hypogaea L.). Journal of soils and crops. 21(2): 266-272.

Jackson, M. L. 1973. Soil Chemical Analysis. Prentice-Hall of India Pvt. Ltd., New Delhi, pp: 497.

Kalamkar, S.S. (2006). Prospects of Contract Farming in India in the Context of Globalisation. Indian Journal of Agricultural Marketing. 20 (3): 25.

Kabir, R., Yeasmin, S., Islam, A.K.M.M. and Sarkar, Md. A. 2013. Effect of Phosphorus, Calcium and Boron on the Growth and Yield of Groundnut (Arachis hypogea L.). Inter. J. Bio-Sci. Bio-Technol., 5 (3): 51- 60.

Namo,O.A.T and Dowyaro,L.L.G. (2009).The influence of rate and time of nitrogen fertilization on nodulation and yield of rain-fed groundnut (Arachis hypogaea L.). Discovery and Innovation. 21(3/4): 50-55.

Patil,K.B., Adsule,R.N. and Kachare, D.P. (1999). Influence of foliar spray of methanol on the growth, nutrient uptake, yield and quality of groundnut. Journal of Maharashtra Agricultural Universities. 24(2): 127-130.

Patra,A.K., Tripathy, S.K. and Samui, R.C. (1995). Effect of post-flowering foliar application of nutrients on growth, yield and economics of rainfed groundnut (Arachis hypogaea L). Indian Journal of Plant Physiology. 38 (3): 203-206.

Pendashtek, M., Tarighi, F., Doustan, H.Z. (2011). Effect of foliar zinc spraying and nitrogen fertilization on seed yield and several attributes of groundnut (Arachis hypogaea L.). World Appl. Sci. J. 13(5):1209-1217.

Roemheld,V. and M.M. El-Fouly. (1999). Foliar nutrient application: Challenge and limits crop production. Proc. 2nd International Workshop on "Foliar Fertilization" April 4-10 Bangkok, Thailand: 1-32.

Sarkar, R.K., Chakraborty, A. and Saha, A . (1999). Effect of foliar application of potassium nitrate and calcium nitrate on groundnut (Arachis hypogaea L.).Indian Journal of Agronomy. 44(4): 809-812.

Vanilarasu, K. and Balakrishnamurthy, G. (2014). Influences of organic manures and amendments in soil physiochemical properties and their impact on growth, yield and nutrient uptake of banana. The Bioscan. 9(2): 525-529.

Veerabhadrappa, B.H. and Yeledhalli, N.A. (2005). Effect of soil and foliar nutrition on partitioning of nutrients at different growth stages of groundnut. Karnataka Journal of Agricultural Sciences. 18(4): 940-945.

Varade, P. A. and Urkude, D. K. 1982. Response of groundnut to sources and levels of potassium. Indian Potash J. 7(1): 2-5. 